\title{
Hubungan Sanitasi Lingkungan Dan Riwayat Penyakit Infeksi Dengan Kejadian Stunting Di Kota Parepare
}

\section{Environmental Sanitation Relations And History Infectious Disease With Stunting Events In The City Of Parepare}

\author{
Sri Wahyuni Abidin ${ }^{(1)}$, Haniarti ${ }^{(1)}$, Rasidah Wahyuni Sari ${ }^{(1)}$ \\ (1) Program Studi Kesehatan Masyarakat Fakultas Ilmu Kesehatan, Universitas Muhammadiyah \\ Parepare, Sulawesi Selatan
}

\author{
Korespondensi Penulis: Sri Wahyuni Abidin, Fakultas Ilmu Kesehatan \\ Universitas Muhammadiyah Parepare \\ Email: wahyuni.health16@gmail.com
}

\begin{abstract}
ABSTRAK
Stunting adalah kondisi dimana balita memiliki panjang atau tinggi badan yang kurang jika dibandingkan dengan umur. Hasil Riskesdas Tahun 2018 diketahui bahwa jumlah balita sangat pendek dan pendek usia 0-59 bulan di Indonesia adalah $11,5 \%$ dan $19,3 \%$. Stunting dapat disebabkan oleh beberapa faktor, diantaranya ialah sanitasi lingkungan dan riwayat penyakit infeksi. Penelitian ini bertujuan untuk mengetahui hubungan antara ketersediaan sumber air bersih, kepemilikan jamban keluarga, riwayat penyakit diare dan riwayat penyakit ISPA dengan kejadian stunting. Metode yang digunakan adalah metode survei analitik dengan pendekatan Cross Sectional Study dan jumlah sampel 275 balita yang berusia 24-59 bulan. Teknik pengambilan sampel dalam penelitian ini adalah Accidental Sampling menggunakan analisis univariat dan analisis bivariat dengan uji Chi-Square, dan waktu penelitian dilakukan pada bulan Juni sampai Agustus Tahun 2020. Hasil analisis uji statistik menunjukkan bahwa tidak terdapat hubungan yang signifikan antara ketersediaan sumber air bersih $(\mathrm{p}=0,319)$, kepemilikan jamban keluarga $(p=0,588)$, riwayat penyakit diare $(p=0,245)$, dan riwayat penyakit ISPA $(p=0,988)$ dengan kejadian stunting. Disarankan kepada peneliti selanjutnya agar melakukan penelitian dengan mengambil variabel lain seperti tinggi orang tua, asupan gizi, riwayat menyusui, dan aktivitas fisik.
\end{abstract}

Kata kunci: Stunting, Air, Jamban, Diare, ISPA

\begin{abstract}
Stunting is a condition in which toddlers have less length or height compared to age. The results of Riskesdas 2018 show that the number of very short and short children aged 0-59 months in Indonesia is $11.5 \%$ and $19.3 \%$. Stunting can be caused by several factors, including environmental sanitation and a history of infectious diseases. This study aims to determine the relationship between the availability of clean water sources, family latrine ownership, a history of diarrhea desease and a history of ISPA desease with the incidence of stunting. The method used is an analytic survey method with a Cross Sectional Study approach and a sample size of 275 toddlers aged 24-59 months. The sampling technique in this study was accidental sampling using univariate analysis and bivariate analysis with the Chi-Square test, and the research was conducted from June to August 2020.The results of statistical test analysis showed that there was no significant relationship between the availability of clean water sources $(p=0,319)$, family latrine ownership $(p=0,588)$, a history of diarrhea disease $(p=0,245)$, and a history of ISPA desease $(p=0,988)$ with the incidence of stunting in the city of Parepare. It is suggested to further researchers $t$ cnduct research by taking other variables such as height f parents, nutritional intake, history of breastfeeding, and physical activity.
\end{abstract}

Keywords: Stunting, Water, Latrines, Diarrhea, ISPA 


\section{PENDAHULUAN}

Stunting ialah keadaan balita yang memiliki panjang atau tinggi badan kurang berdasarkan umurnya. Pada tahun 2017 sebanyak $22,2 \%$ atau sekitar 150,8 juta balita di dunia terkena stunting. Dari 83,6 juta balita stunting di Asia, jumlah terbanyak berada di Asia Selatan yaitu 58,7\% dan paling sedikit di Asia Tengah yaitu $0,9 \%$. Menurut World Health Organization (WHO), Indonesia menjadi negara ke-3 dengan jumlah stunting tertinggi di regional Asia Tenggara/South-East Asia Regional dengan rata-rata prevalensi $36,4 \%$ tahun 2005-2017 dimana negara tertinggi pertama ialah Timor Leste 50,2\% disusul India 38,4\%, dan urutan ke-5 dengan jumlah stunting tertinggi di dunia (Kemenkes RI, 2018b).

Data Pemantauan Status Gizi (PSG) menunjukkan bahwa kategori pendek memiliki prevalensi tertinggi dibandingkan dengan masalah gizi lainnya seperti gizi kurang, kurus, dan gemuk. Hasil Riset Kesehatan Dasar (Riskesdas) tahun 2018 diketahui bahwa di Indonesia prevalensi balita sangat pendek dan pendek masing-masing $11,5 \%$ dan 19,3\%. Berdasarkan data Pemantauan Status Gizi (PSG) dari 34 provinsi yang ada di Indonesia, Sulawesi Selatan berada di urutan ke-4 dengan prevalensi balita stunting sebesar 35,7\%. Provinsi dengan prevalensi tertinggi balita stunting adalah Nusa Tenggara Timur sebesar $42,7 \%$, sedangkan provinsi dengan prevalensi terendah adalah DKI Jakarta sebesar 17,6\% (Kemenkes RI, 2018a).

Pada Tahun 2019 bulan Desember prevalensi balita stunting di Kota Parepare sebanyak 455 balita sangat pendek dan 707 balita pendek, jadi total balita stunting ialah 1162 balita (Dinkes Kota Parepare, 2019). Stunting adalah masalah gizi yang disebabkan oleh beberapa faktor, diantaranya ialah sanitasi lingkungan dan riwayat penyakit infeksi (Wulandari et al., 2019). Keluarga yang tidak memiliki akses air bersih secara signifikan 3 kali lebih besar menderita stunting dibandingkan keluarga yang memiliki akses air bersih (Ahmad \& Indah, 2019).

Kepemilikan jamban berhubungan dengan kejadian stunting. Kepemilikan jamban yang tidak layak cenderung menderita stunting 7,398 kali lebih tinggi dibandingkan dengan balita yang mempunyai jamban yang layak (Nasrul, 2018). Akses sanitasi merupakan salah satu faktor yang mempengaruhi kejadian stunting. Di Indonesia diketahui bahwa 1 dari 5 rumah tangga masih buang air besar (BAB) diruang terbuka, serta 1 dari 3 rumah tangga belum memiliki akses ke air minum bersih (TNP2K, 2017). Akses sanitasi dikatakan layak apabila memenuhi syarat kesehatan diantaranya dilengkapi dengan leher angsa, tanki septik (septic tank)/Sistem Pengolahan Air Limbah (SPAL), yang digunakan sendiri atau bersama (Kemenkes RI, 2018b).

Anak balita dengan riwayat diare berisiko 13,33 kali menjadi stunting, dan anak balita dengan riwayat ISPA berisiko 7,01 kali menjadi stunting (Yuniarti et al., 2019). Penyakit infeksi ada anak balita memungkinkan terjadinya penurunan berat badan dan apabila hal tersebut berlangsung dalam waktu yang cukup lama serta tidak diimbangi dengan pemberian asupan yang cukup sebagai proses penyembuhan maka dapat menyebabkan stunting (Kemenkes RI, 2018b).

Berdasarkan latar belakang di atas, maka peneliti tertarik melakukan penelitian mengenai "Hubungan Sanitasi Lingkungan dan Riwayat Penyakit Infeksi Terhadap Kejadian Stunting di Kota Parepare".

\section{SUBYEK DAN METODE}

Metode penelitian yang digunakan adalah metode survei analitik dengan pendekatan Cross Sectional Study yang menjelaskan hubungan variabel-variabel yang ingin diteliti. Penelitian ini dilaksanakan di wilayah kerja ke-6 Puskesmas yang ada di Kota Parepare pada bulan Juni hingga bulan Agustus tahun 2020. Populasi dalam penelitian ini adalah semua balita yang ada di Kota Parepare yaitu sebanyak 4.351 balita. Minimal sampel yang diperlukan yang diperlukan ialah sebanyak 275 balita yang berusia 24-59 bulan. Teknik sampling yang digunakan adalah teknik Accidental Sampling.

Data primer diambil dari responden atau sampel penelitian berupa karakteristik responden. Data sekunder diperoleh dari data yang sudah ada dan tersedia di setiap puskesmas. Instrumen yang digunakan berupa microtoise untuk mengukur tinggi badan balita dan kuesioner yang diberikan kepada responden. Analisis data yaitu univariat dan bivariat dengan uji Chi Square $(\mathrm{p}=0,05)$ kemudian disajikan dalam bentuk tabel. 
HASIL

Tabel 1. Distribusi Karakteristik Responden di Kota Parepare

\begin{tabular}{|c|c|c|}
\hline $\begin{array}{l}\text { Variabel } \\
\end{array}$ & $n=275$ & $\%$ \\
\hline \multicolumn{3}{|l|}{ Jenis Pekerjaan } \\
\hline IRT & 214 & 77,8 \\
\hline Wiraswasta & 28 & 10,2 \\
\hline PNS & 14 & 5,1 \\
\hline Karyawan Swasta & 11 & 4,0 \\
\hline Lainnya & 8 & 2,9 \\
\hline \multicolumn{3}{|l|}{ Pendidikan } \\
\hline Tidak sekolah & 2 & 0,7 \\
\hline SD & 16 & 5,8 \\
\hline SMP/sederajat & 68 & 24,7 \\
\hline SMA/sederajat & 147 & 53,5 \\
\hline $\mathrm{D} 3 / \mathrm{PT}$ & 42 & 15,3 \\
\hline \multicolumn{3}{|l|}{$\begin{array}{lll}\text { Kelompok } & \text { Umur } & \text { Balita } \\
\text { (Bulan) }\end{array}$} \\
\hline $24-35$ & 107 & 38,9 \\
\hline $36-47$ & 103 & 37,5 \\
\hline $48-59$ & 65 & 23,6 \\
\hline \multicolumn{3}{|l|}{ Jenis Kelamin Balita } \\
\hline Laki-laki & 136 & 49,5 \\
\hline Perempuan & 139 & 50,5 \\
\hline \multicolumn{3}{|l|}{ Status Gizi Balita } \\
\hline Stunting & 128 & 46,5 \\
\hline Normal & 147 & 53,5 \\
\hline \multicolumn{3}{|l|}{ Jenis Sumber Air Minum } \\
\hline Air Ledeng & 73 & 26,5 \\
\hline Air Kemasan (Air galon) & 161 & 58,5 \\
\hline Sumur bor atau pompa & 41 & 14,9 \\
\hline Penampungan Air Hujan & 0 & 0,0 \\
\hline Air Sungai & 0 & 0,0 \\
\hline \multicolumn{3}{|l|}{ Bangunan Jamban } \\
\hline Tidak ada & 11 & 4,0 \\
\hline $\begin{array}{l}\text { Bangunannya kuat dan } \\
\text { tertutup }\end{array}$ & 260 & 94,5 \\
\hline $\begin{array}{l}\text { Bangunannya tidak kuat } \\
\text { dan tidak tertutup }\end{array}$ & 4 & 1,5 \\
\hline \multicolumn{3}{|l|}{$\begin{array}{l}\text { Riwayat Penyakit Diare } \\
\text { dalam } 2 \text { Bulan Terakhir }\end{array}$} \\
\hline Ya & 46 & 16,7 \\
\hline Tidak & 229 & 83,3 \\
\hline
\end{tabular}


Tabel 1 menunjukkan bahwa distribusi responden berdasarkan jenis pekerjaan yang paling banyak ialah IRT yaitu sebanyak 214 orang $(77,8 \%)$, dan paling sedikit ialah jenis pekerjaan dalam kategori lainnya yaitu sebanyak 8 orang (2,9\%). Pada distribusi responden berdasarkan pendidikan menunjukkan bahwa pendidikan responden yang paling banyak ialah SMA/sederajat yaitu sebanyak 147 orang $(53,5 \%)$, dan paling sedikit ialah responden yang tidak sekolah yaitu sebanyak 2 orang $(0,7 \%)$. Adapun distribusi responden berdasarkan kelompok umur balita yang paling banyak ialah kelompok 24-35 yaitu sebanyak 107 orang $(38,9 \%)$, dan paling sedikit kelompok 48-59 yaitu sebanyak 65 orang $(23,6 \%)$.

Selanjutnya, distribusi responden berdasarkan jenis kelamin balita menunjukkan bahwa jenis kelamin balita yang paling banyak ialah perempuan yaitu sebanyak 139 orang $(50,5 \%)$, dan paling sedikit ialah laki-laki yaitu sebanyak 136 orang (49,5\%). Pada status gizi balita, Distribusi responden menunjukkan bahwa balita dengan status normal lebih banyak yaitu sebanyak 147 orang $(53,5 \%)$, dibandingkan dengan balita stunting yaitu sebanyak 128 orang (46,5\%). Distribusi responden berdasarkan jenis sumber air minum yang paling banyak digunakan ialah air kemasan/air galon yaitu sebanyak 161 orang $(58,5 \%)$, dan paling sedikit ialah air sumur bor atau pompa yaitu sebanyak 41 orang $(14,9 \%)$.

Berdasarkan bangunan jamban, distribusi responden menunjukkan bahwa kebanyakan responden telah memiliki bangunan jamban yang kuat dan tertutup yaitu sebanyak 260 orang $(94,5 \%)$. Adapun distribusi responden berdasarkan riwayat penyakit diare dalam 2 bulan menunjukkan bahwa sebanyak 46 balita $(16,7 \%)$ yang memiliki riwayat penyakit diare dalam 2 bulan terakhir, dan sebanyak 229 balita (83,3\%) yang tidak memiliki riwayat penyakit diare dalam 2 bulan terakhir.

Distribusi responden berdasarkan riwayat menderita penyakit ISPA dalam 2 bulan terakhir menunjukkan bahwa sebanyak 114 balita $(41,5 \%)$ yang memiliki riwayat penyakit seperti yang disajikan dalam tabel 2 berikut:

Tabel 2. Distribusi Responden Berdasarkan Riwayat Penyakit ISPA di Kota Parepare

\begin{tabular}{lcc}
\hline $\begin{array}{l}\text { Riwayat Penyakit ISPA dalam } \mathbf{2} \\
\text { Bulan Terakhir }\end{array}$ & $\mathbf{n = 2 7 5}$ & \% \\
\hline Ya & 114 & 41,5 \\
Tidak & 161 & 58,5 \\
\hline
\end{tabular}

Tabel 3. Hubungan Variabel Independen dengan Kejadian Stunting di Kota Parepare

\begin{tabular}{|c|c|c|c|c|c|c|c|}
\hline \multirow{3}{*}{ Variabel Independen } & \multicolumn{6}{|c|}{ Status Gizi } & \multirow{3}{*}{ Nilai $\mathbf{p} *$ ) } \\
\hline & \multicolumn{2}{|c|}{ Stunting } & \multicolumn{2}{|c|}{ Normal } & \multicolumn{2}{|c|}{ Total } & \\
\hline & $n=128$ & $\%$ & $\mathrm{n}=147$ & $\%$ & $n=275$ & $\%$ & \\
\hline \multicolumn{8}{|l|}{$\begin{array}{l}\text { Ketersediaan Sumber Air } \\
\text { Bersih }\end{array}$} \\
\hline Layak & 49 & 38,3 & 65 & 44,2 & 114 & 41,5 & \multirow{2}{*}{0,319} \\
\hline Tidak Layak & 79 & 61,7 & 82 & 55,8 & 161 & 58,5 & \\
\hline \multicolumn{8}{|l|}{$\begin{array}{l}\text { Kepemilikan Jamban } \\
\text { Keluarga }\end{array}$} \\
\hline Layak & 120 & 93,8 & 140 & 95,2 & 260 & 94,5 & \multirow{2}{*}{0,588} \\
\hline Tidak Layak & 8 & 6,2 & 7 & 4,8 & 15 & 5,5 & \\
\hline \multicolumn{8}{|l|}{ Riwayat Penyakit Diare } \\
\hline Memiliki Riwayat & 25 & 19,5 & 21 & 14,3 & 46 & 16,7 & \multirow{2}{*}{0,245} \\
\hline Tidak Memiliki Riwayat & 103 & 80,5 & 126 & 85,7 & 229 & 83,3 & \\
\hline \multicolumn{8}{|l|}{ Riwayat Penyakit ISPA } \\
\hline Memiliki Riwayat & 53 & 41,4 & 61 & 41,5 & 114 & 41,5 & \multirow{2}{*}{0,988} \\
\hline Tidak Memiliki Riwayat & 75 & 58,6 & 86 & 58,5 & 161 & 58,5 & \\
\hline
\end{tabular}

*) signifikan jika nilai $p \leq 0,05$ 
Tabel 3 menunjukkan bahwa distribusi responden berdasarkan ketersediaan sumber air bersih yang layak sebanyak 49 balita $(38,3 \%)$ mengalami stunting dan 65 balita $(44,2 \%)$ tidak mengalami stunting. Sedangkan responden yang memiliki ketersediaan sumber air bersih tidak layak sebanyak 79 balita $(61,7 \%)$ mengalami stunting dan 82 balita $(55,8 \%)$ tidak mengalami stunting. Dimana diperoleh nilai $p=$ $0,319,(p>0,05)$. Adapun distribusi responden berdasarkan kepemilikan jamban keluarga yang layak menunjukkan bahwa sebanyak 120 balita (93,8\%) mengalami stunting dan 140 balita $(95,2 \%)$ tidak mengalami stunting. Sedangkan responden yang memiliki jamban keluarga tidak layak sebanyak 8 balita $(6,2 \%)$ mengalami stunting dan 7 balita $(4,8 \%)$ tidak mengalami stunting. Dimana diperoleh nilai $p=$ $0,588(p>0,05)$.

Berdasarkan riwayat penyakit diare, distribusi responden menunjukkan bahwa sebanyak 25 balita $(19,5 \%)$ mengalami stunting dan 21 balita $(14,3 \%)$ tidak mengalami stunting. Sedangkan responden yang tidak riwayat penyakit diare sebanyak 103 balita (80,5\%) mengalami stunting dan 126 balita $(85,7 \%)$ tidak mengalami stunting. Dimana diperoleh nilai $p=0,245,(p>0,05)$. Adapun, distribusi responden berdasarkan riwayat penyakit ISPA menunjukkan bahwa sebanyak 53 balita $(41,4 \%)$ mengalami stunting dan 61 balita $(41,5 \%)$ tidak mengalami stunting. Sedangkan responden yang tidak riwayat penyakit ISPA sebanyak 75 balita $(58,6 \%)$ mengalami stunting dan 86 balita $(58,5 \%)$ tidak mengalami stunting. Dimana diperoleh nilai $p=$ $0,988,(p>0,05)$.

\section{DISKUSI}

Keterbatasan dalam penelitian ialah pada proses pengumpulan data. Dikarenakan kondisi di Indonesia pada saat penelitian berlangsung sedang marak wabah Covid-19 sehingga peneliti mengalami hambatan untuk berintraksi langsung dengan responden. Kegiatan Posyandu yang biasanya dilakukan oleh petugas puskesmas terpaksa diberhentikan untuk beberapa bulan untuk menghindari terjadinya kerumunan. Sehingga penelitian yang seharusnya dilakukan pada saat posyandu berlangsung diubah menjadi kejar timbang yaitu mendatangi rumah responden satu per satu namun tetap mengikuti protokol kesehatan dengan memakai masker, hand sanitaizer, dan hand skull. Hal tersebut cukup memakan waktu dan tenaga.

\section{Hubungan Ketersediaan Sumber Air Bersih dengan Kejadian Stunting}

Sumber air minum baik dan layak ialah air minum yang terlindung termasuk air ledeng (keran), hydrant umum, keran umum, air PAH terminal, atau mata air dan sumur terlindung, sumur bor atau pompa, dengan jaraknya minimal 10 meter dari pembuangan kotoran, penampungan limbah, dan pembuangan sampah. Hal ini tidak termasuk air kemasan, air yang dijual melalui tangki, air dari penjual keliling, air sumur dan mata air tidak terlindung (Kemenkes RI, 2018b). Hasil analisis diperoleh nilai $p=0,319$, yang berarti bahwa tidak terdapat hubungan signifikan antara ketersediaan sumber air bersih dengan kejadian stunting di Kota Parepare. Hasil penelitian yang sejalan menyatakan bahwa di wilayah kerja Puskesmas Temon II akses air bersih tidak berhubungan dengan anak stunting usia 24-59 bulan, akses air bersih hanya menjadi faktor protektif atau faktor pencegah terjadinya stunting (Hendraswari, 2019).

Penelitian lain menyatakan bahwa terdapat hubungan yang signifikan antara ketersediaan sumber air bersih dengan kejadian stunting. Keluarga yang tidak memiliki akses air bersih secara signifikan berisiko 3 kali lebih tinggi menderita kejadian stunting bila dibandingkan dengan keluarga yang memiliki akses air bersih (Ahmad \& Indah, 2019). Tidak adanya hubungan ketersediaan sumber air bersih sebagai sumber air minum dengan kejadian stunting dikarenakan pada penelitian ini hanya dilakukan analisis terhadap sumber air minum yang digunakan tanpa memperhatikan kualitas fisik air yang digunakan serta bagaimana cara pengolahan air minum yang dikonsumsi.

\section{Hubungan Kepemilikan Jamban Keluarga dengan Kejadian Stunting}

Jamban yang tidak memenuhi standar akan memicu penyakit infeksi dikarenakan higiene dan sanitasi yang buruk sehingga dapat menghambat penyerapan zat gizi dalam pencernaan (Kemenkes RI, 2018b). Hasil analisis diperoleh nilai $p=0,588$, berarti bahwa tidak terdapat hubungan signifikan antara kepemilikan jamban keluarga dengan kejadian stunting di Kota Parepare. Pada penelitian ini kebanyakan responden yang anak balitanya mengalami stunting ialah yang memiliki jamban keluarga yang layak. Hasil penelitian 
ini didukung oleh salah satu penelitian yang menyatakan bahwa tidak terdapat hubungan antara kepemilikan jamban dengan balita stunting usia 24-59 bulan yang artinya hal tersebut tidak termasuk faktor risiko kejadian stunting (Hendraswari, 2019).

Hasil penelitian Nasrul (2018) menyatakan bahwa ada hubungan yang bermakna antara kepemilikan jamban yang tidak layak dengan kejadian stunting. Balita dengan kepemilikan jamban yang tidak layak berisiko mengalami stunting 7,398 kali lebih tinggi daripada balita dengan kepemilikan jamban yang layak (Nasrul, 2018). Tidak adanya hubungan dalam penelitian ini dikarenakan hampir seluruh responden telah mempunyai jamban keluarga yang baik seperti jamban dengan bangunan kuat, berjenis leher angsa, dan memiliki tangki septik. Meski demikian, belum ada analisis lebih lanjut mengenai higiene dari jamban dan perilaku mencuci tangan setelah balita buang air besar. Penelitian lain juga menunjukkan bahwa kebiasaan cuci tangan ada hubungan dengan kejadian stunting di wilayah kerja Puskesmas Kotakulon Kabupaten Bondowoso. Kebiasaan cuci tangan yang kurang baik berisiko 0,12 kali mengalami stunting (Sinatrya \& Muniroh, 2019).

\section{Hubungan Riwayat Penyakit Diare dengan Kejadian Stunting}

Menurunnya nafsu makan yang diakibatkan oleh penyakit infeksi dapat mengganggu absorpsi nutrien, kehilangan zat gizi mikro secara langsung, metabolisme bertambah, kehilangan nutrien akibat katabolisme yang menjadi tinggi, gangguan perjalanan nutrien ke jaringan. Terjadinya gangguan asupan nutrisi ini akan mengakibatkan terganggunya pertumbuhan anak. Penyakit yang sering dijumpai pada anak ialah diare, infeksi cacing, infeksi saluran pernapasan, inflamasi, malaria, serta terjadinya penurunan selera makan dikarenakan infeksi (Hardianty, 2019). Diare adalah salah satu penyakit infeksi yang ditandai dengan meningkatnya pengeluaran tinja yang konsistensinya lebih lembek atau encer dari biasanya dan terjadi paling sedikit 3 kali dalam sehari. Diare biasanya disebabkan oleh bakteri E. Coli. Jika diare berlangsung lama dan sering maka dapat menyebabkan terhambatnya pertumbuhan balita (Fatkhiyah, 2016).
Hasil analisis diperoleh nilai $p=0,245$, yang berarti bahwa tidak terdapat hubungan signifikan antara riwayat penyakit diare dengan kejadian stunting di Kota Parepare. Hal ini sejalan dengan hasil penelitian yang menyatakan bahwa penyakit infeksi diare dan balita stunting usia 24-59 bulan tidak terdapat hubungan (Hendraswari, 2019). Penelitian lain juga menemukan adanya hubungan yang signifikan antara riwayat penyakit diare dengan kejadian stunting. Balita dengan riwayat diare dalam 2 bulan terakhir berisiko 5,04 kali mengalami stunting daripada balita tanpa riwayat diare dalam waktu 2 bulan terakhir (Lestari Wanda et al., 2014 dalam Pibriyanti et al., 2019).

Tidak adanya hubungan dalam penelitian ini dikarenakan dampak yang ditimbulkan dari diare ialah berat badan yang berkurang bukan penghambat tinggi badan. Anak yang menderita diare biasanya disertai anoreksia dan dehidrasi, jika tidak segera diatasi maka akan berdampak pada menurunnya berat badan yang merupakan gejala malnutrisi akut, sedangkan stunting ialah gejala malnutrisi kronis yang berulang-ulang. Hal tersebut juga dapat dipengaruhi oleh lamanya infeksi yang diderita (Setiawan et al., 2018). Riwayat diare dalam penelitian ini juga hanya diukur dalam kurung waktu 2 bulan tanpa memperhatikan adanya riwayat penyakit infeksi di tahun sebelumnya dan kemungkinan terjadinya kekeliruan pada saat wawancara dilakukan sehingga tidak ditemukan hubungan yang bermakna.

\section{Hubungan Riwayat Penyakit ISPA dengan Kejadian Stunting}

Infeksi saluran pernafasan akut (ISPA) adalah penyakit yang memiliki gejala seperti batuk, pilek, serak, demam, dengan atau tanpa disertai nafas cepat atau sesak nafas yang berlangsung selama 14 hari. ISPA yang dialami anak biasanya disertai peningkatan suhu tubuh. Apabila terus terjadi dan berlangsung lama tanpa diimbangi dengan asupan nutrisi yang cukup maka akan menyebabkan dehidrasi, malnutrisi dan gagal tumbuh (Pibriyanti et al., 2019).

Hasil analisis diperoleh nilai $p=0,988$, yang berarti bahwa tidak terdapat hubungan signifikan antara riwayat penyakit ISPA dengan kejadian stunting di Kota Parepare. Hal ini sejalan dengan penelitian yang menyatakan tidak terdapat hubungan yang signifikan antara penyakit ISPA dengan anak stunting usia 24-59 
bulan. Namun anak yang sering terkena ISPA berpeluang 2,78 kali terkena stunting dibandingkan anak yang jarang terkena ISPA. Faktor penyakit infeksi termasuk faktor risiko stunting (Hendraswari, 2019).

Penelitian lain juga menyatakan bahwa terdapat hubungan yang signifikan antara riwayat penyakit ISPA dengan kejadian stunting. Anak yang mengalami ISPA berisiko 5,71 kali menderita stunting daripada anak yang belum pernah mengalami ISPA dalam 2 bulan terakhir (Lestari Wanda, et al., 2014 dalam Pibriyanti et al., 2019). Tidak adannya hubungan yang bermakna dalam penelitian ini dimungkinkan karena ISPA merupakan penyakit infeksi yang umum terjadi dan rentan menular pada anak balita. Infeksi tersebut tergolong ringan dimana demam yang disertai pilek namun jarang ada yang menimbulkan batuk. Infeksi tersebut juga dapat cepat sembuh dengan sendirinya dan berdasarkan hasil wawancara kebanyakan responden membawa anak balitanya ke tenaga kesehatan ketika masih berumur kurang dari satu tahun, selanjutanya responden hanya memberikan pengobatan tradisional dan membelikan obat di apotek terdekat ketika anak balitanya mengalami ISPA. Selain itu gejala yang ditimbulkan kemungkinan tidak menyebabkan gangguan pada nafsu makan anak balita sehingga tidak menurunkan status gizi anak balita.

Stunting adalah masalah gizi yang dapat disebabkan oleh berbagai faktor. Pada penelitian tidak terdapat hubungan antara variabel independen dengan kejadian stunting. Adapun faktor lain yang dapat mepengaruhi kejadian stunting pada balita ialah BBLR, tingkat pendidikan dan sosial ekonomi. BBLR berpengaruh terhadap kejadian stunting di Kawasan Pesisir Kecamatan Suppa Kabupaten Pinrang. Bagi perempuan yang lahir dengan berat badan rendah, beresiko menjadi ibu stunting sehingga cenderung akan melahirkan bayi dengan berat lahir seperti dirinya (Sutriana et al., 2020).

Pendidikan ibu dan status sosial ekonomi keluarga juga berpengaruh terhadap kejadian stunting pada balita di Salo Kabupaten Pinrang. Pendidikan Ibu merupakan faktor yang sangat penting. Tinggi rendahnya tingkat pendidikan Ibu erat kaitannya dengan tingkat pengetahuan terhadap perawatan kesehatan, kehamilan dan pasca persalinan, serta kesadaran terhadap kesehatan dan gizi anak-anak dan keluarganya. Serta dapat menentukan mudah tidaknya seseorang menyerap dan memahami pengetahuan gizi yang telah diperoleh (Daming et al., 2019). Status sosial ekonomi keluarga dapat dilihat dari pendapatan suatu keluarga. Responden yang memiliki balita stunting kebanyakan yang memperoleh pendapatan dalam kategori rendah, sehingga beberapa responden berasumsi bahwa pendapatan yang mereka dapatkan masih sangat kurang untuk dapat memenuhi kebutuhan mereka sehari-hari. Ibu lebih memilih produk makanan yang murah untuk diberikan kepada anak balitanya. Mereka juga tidak mempedulikan kandungan gizi yang terdapat pada setiap produk makanan yang mereka beli sehingga makanan yang dikomsumsi tidak memiliki gizi yang cukup baik bagi pertumbuhan dan perkembangan anak mereka (Daming et al., 2019).

\section{KESIMPULAN}

Berdasarkan hasil penelitian yang telah dilakukan di wilayah kerja ke-6 puskesmas Kota Parepare maka diperoleh kesimpulan bahwa tidak ada hubungan antara ketersediaan sumber air bersih, kepemilikan jamban keluarga, riwaya penyakit diare, dan riwayat penyakit ISPA dengan kejadian stunting di Kota Parepare. Dari kesimpulan tersebut maka disarankan kepada peneliti selanjutnya agar melakukan penelitian dengan mengambil variabel lain seperti tinggi orang tua, asupan gizi, riwayat menyusui, dan aktivitas fisik. Dapat pula melakukan penelitian dengan variabel yang sama yaitu ketersediaan sumber air bersih namun lebih mengarah pada kualitas fisik air dan cara pengolahan air yang digunakan serta variabel riwayat penyakit infeksi namun frekuensi dan durasi yang berbeda atau lebih lama dan dengan metode yang berbeda.

\section{DAFTAR PUSTAKA}

Ahmad, Z. F., \& Indah, S. S. N. 2019. Faktor Lingkungan dan Perlaku Orang Tua pada Balita Stunting di Kabupaten Gorontalo. Jurnal Ilmiah Umum Dan Kesehatan, 4(2), 87-96.

Daming, H., Hengky, H. K., \& Umar, F. 2019. Faktor-Faktor yang Mempengaruhi Kejadian Stunting pada Balita di Puskesmas Salo Kabupaten Pinrang. Jurnal Ilmiah Manusia Dan Kesehatan, 2(1), 59-67.

Dinkes Kota Parepare. 2019. Laporan Kegiatan 
Pemantauan Status Gizi Tahun 2019.

Fatkhiyah. 2016. Gambaran Kejadian Diare pada Balita di Wilayah Kerja Puskesmas Wedung II. Fakultas Kesehatan Masyarakat. Universitas Muhammadiyah Semarang: Semarang.

Hardianty, R. 2019. Hubungan Pola Asuh Ibu dengan Kejadian Stunting Anak Usia 24-59 Bulan di Kecamatan Jelbuk Kabupaten Jember. Fakultas Kedokteran. Universitas Jember: Jember.

Hendraswari, C. A. 2019. Determinan Anak Stunting Usia 24-59 Bulan Di Wilayah Kerja Puskesmas Temon Ii Kabupaten Kulon Progo Tahun 2019. Jurusan Kebidanan. Politeknik Kesehatan Kementrian Kesehatan Yogyakarta : Yogyakarta.

Kemenkes RI. 2018a. Laporan Nasional Riset Kesehatan Dasar (Riskesdas) Indonesia Tahun 2018. In Riset Kesehatan Dasar 2018. Badan Penelitian dan Pengembangan Kesehatan: Jakarta.

Kemenkes RI. 2018b. Situasi Balita Pendek (Stunting) di Indonesia. Pusat Data dan Informasi Kesehatan, Kementerian Kesehatan RI. In Buletin Jendela Data dan Informasi Kesehatan (Semester I). Kemenkes RI: Jakarta.

Nasrul. 2018. Pengendalian Faktor Risiko Stunting Anak Balita di Sulawesi Tengah. Jurnal Kesehatan Masyarakat, 8(2), 131-146.

Pibriyanti, K., Suryono, \& Luthfi, C. A. 2019. Faktor-Faktor yang Berhubungan dengan Kejadian Stunting pada Balita di Wilayah Kerja Puskesmas Slogohimo Kabupaten Wonogiri. Darussalam Nutrition Journal, 3(2), 42-49.

Setiawan, E., Machmud, R., \& Masrul, M. 2018.
Faktor-Faktor yang Berhubungan dengan Kejadian Stunting pada Anak Usia 24-59 Bulan di Wilayah Kerja Puskesmas Andalas Kecamatan Padang Timur Kota Padang Tahun 2018. Jurnal Kesehatan Andalas, 7(2), 275-284.

Sinatrya, A. K., \& Muniroh, L. 2019. Hubungan Faktor Water, Sanitation, and Hygiene (WASH) dengan Stunting di Wilayah Kerja Puskesmas Kotakulon, Kabupaten Bondowoso. Amerta Nutrition, 3(3), 164170.

Sutriana, Usman, \& Umar, F. 2020. Analisis Faktor Resiko Kejadian Stunting pada Balita di Kawasan Pesisir Kabupaten Pinrang. Jurnal Ilmiah Manusia Dan Kesehatan, 3(3), 432443.

TNP2K. 2017. 100 Kabupaten/Kota Prioritas Untik Intervensi Anak Kerdil (Stunting). Tim Nasional Percepatan Penanggulangan Kemiskinan: Jakarta.

Utami, R. A. 2018. Dampak Sanitasi Lingkungan Terhadap Kesehatan Masyarakat di Wilayah Pesisir Kecamatan Kota Agung Kabupaten Tanggamus Provinsi Lampung. Fakultas Keguruan dan Ilmu Pendidikan. Universitas Lampung: Bandar Lampung.

Wulandari, Rahayu, F., \& Darmawansyah. 2019. Hubungan Sanitasi Lingkungan dan Riwayat Penyakit Infeksi dengan Kejadian Stunting di Wilayah Kerja Puskesmas Kerkap Kabupaten Bengkulu Utara Tahun 2019. Jurnal Ilmiah Avicenna, 14(2), 6-13.

Yuniarti, T. S., Margawati, A., \& Nuryanto. 2019. Faktor Risiko Kejadian Stunting Anak Usia 1-2 Tahun di Daerah Rob Kota Pekalongan. Jurnal Riset Gizi, 7(2), 83-90. 